\title{
Independent consultancy in drug discovery and development: a personal perspective
}

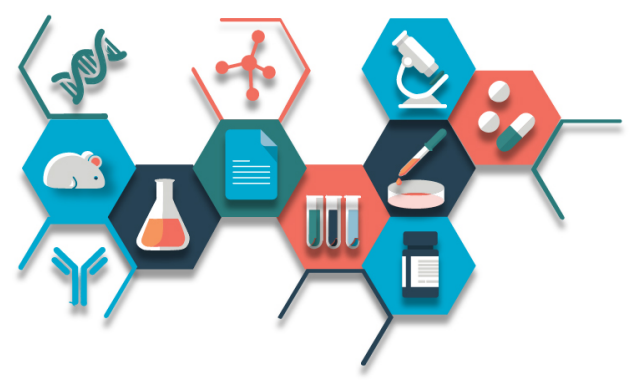

\author{
Pauline T Lukey*,1 \\ ${ }^{1}$ Target to Treatment Consulting Ltd, Stevenage BioScience Catalyst, Stevenage, UK \\ *Author for correspondence: paulinelukey@target2treatment.com
}

First draft submitted: 28 January 2019; Accepted for publication: 18 March 2019; Published online: 28 May 2019

Keywords: biotech $\bullet$ consulting $\bullet$ contracts $\bullet$ insurance $\bullet$ networking $\bullet$ premises $\bullet$ professional development

\section{Biography}

PT Lukey received her BSc and MSc in genetics and microbiology from the University of the Witwatersrand, Johannesburg (South Africa) and her DSc in immunology from the University of Pretoria (South Africa). She then pursued postdoctoral research in tuberculosis and rheumatoid arthritis within the Department of Medicine, Groote Schuur Hospital, University of Cape Town (South Africa). After moving to the UK, she joined GlaxoSmithKline (GSK; London, UK) R\&D where she remained for 20 years, moving through various leadership roles in discovery and development of new medicines. She gained experience in a variety of therapy areas, molecular targets and drug modalities (including tuberculosis, rheumatoid arthritis and fibrosis). Since retiring from GSK in 2015, she has been working as an independent consultant at Stevenage BioScience Catalyst (UK).

\section{Please tell us about your background}

I retired after a 20-year career in the pharmaceutical industry in December 2015 with a view to becoming an independent consultant. My objective was to increase my autonomy, improve my work/life balance and experience the biotech world. So, here I am, 3 years later, ready to share my experiences.

\section{What are the first steps to move from the pharma industry to consulting?}

\section{Individual consultant or limited company}

There is a choice to be made: work as an individual (sole trader) or set up a limited company. A comparison of the advantages and disadvantages of these options is available [1]. I decided to form a limited company to maintain more financial flexibility and control. The process is relatively straightforward in the UK [2], does not cost much and does not take long. Having said all of that, I asked my accountant to do it for me (you would probably need an accountant anyway). The name of your new consulting company must be unique, and this can be checked at the above website, or a similar national database. I chose a name that tries to convey quite literally what I do (Target to Treatment), but other options include using your name and adding 'consulting Ltd' or something more fanciful. One should remember to check the acronym too (e.g., TTT is acceptable but Fast Action Research Team Ltd should be avoided). If you decide to set up a limited company then you will need a business bank account which requires time to set up. Note that the new 'general data protection' legislation in Europe (GDPR; [3]) may affect your business if you retain personal information as part of your services.

\section{Insurance}

You will also need insurance, particularly professional indemnity; in addition, you should consider employers' liability (if you have more than one share holder) and public liability. Some clients ask to review your insurance documents and may have specific requirements. Other considerations include the type of consulting that you provide, for example advice on clinical trial design requires a higher level of insurance. Also, the geographic area that needs to be covered (UK, EU, USA, rest of world) will affect your premiums. The best way forward is to speak to an insurance broker who specializes in the pharmaceutical industry. You should shop around to get the best deal. 


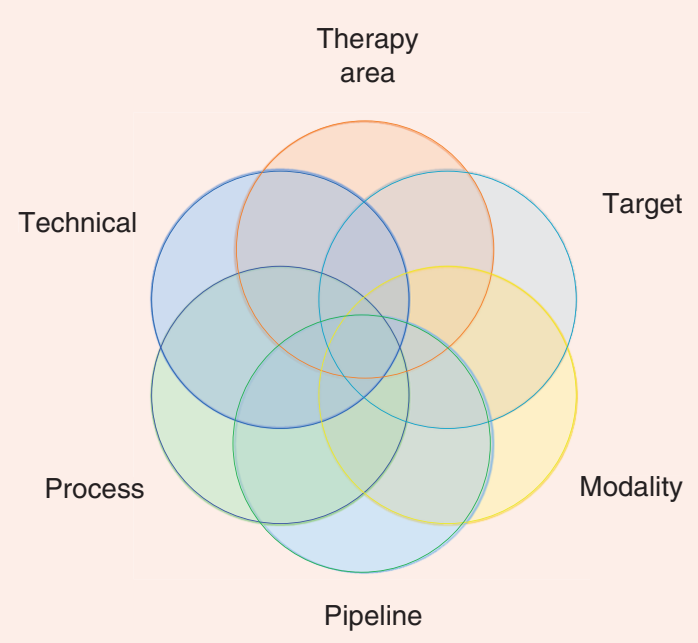

Figure 1. Potential areas of expertise that determine your ability to consult. The 'sweet spot' is in the center where all your areas of expertise are engaged equally; however, that is rare. It is usually the case that at least one area of expertise is highly relevant with several other areas that are less strong. Based on a solid foundation of relevant expertise, it is also possible to start to branch out into new areas.

\section{Premises}

Premises are another important decision that needs to be made. Working from home is attractive if you have a dedicated space that allows you to separate 'work' from 'home'. I tried this in the beginning but found that the boundaries between home and work became blurred. So, I rented office space nearby in a local industrial estate. This was very convenient but relatively expensive. In addition, the other occupants of the building were in very different industries and, while it was interesting to meet other professions, it did not help with networking. So, I am now a tenant at the Stevenage Bioscience Catalyst (other science parks are available in the UK [4] and internationally). This has the advantage that I am surrounded by people and companies engaged in the science of drug discovery and development, which is great for networking. In addition, I have access to the scientific literature as part of my tenancy; this is an invaluable asset for a consultant.

\section{Networking}

A separate word about networking is important. I cannot emphasize enough the importance of maintaining, growing and fostering your network. Not only is this the pool from which your future clients are likely to emerge, either directly or indirectly, but also your consultant peers. I have known and worked with many of the people in my network for years, decades in some cases, and they form the core of my network. We know, respect and trust each other and are comfortable cross-referring clients and sharing best practice. Beyond that core group, I have made valuable new contacts through introductions from my core network members, at scientific meetings and among other tenants at the bioscience park. You should make sure your network knows that you are available for consulting by using professional social media such as LinkedIn, making sure to keep your profile up-to-date. The best and most effective way to find clients, and for clients to find you, is by word of mouth, so you should protect your reputation. Your network is also your support group, consulting can be a lonely job.

\section{What does working as an independent consultant entail?}

\section{Areas of expertise}

There are different types of consultants with different business models. This is largely dictated by your previous experience that forms the basis of your ability to consult (Figure 1).

- Technical expertise relates to your academic qualifications

- Examples are medicinal chemistry, epidemiology, statistics, bioinformatics, biomarkers, preclinical models, pharmacology, screening sciences, the list goes on. 
- Therapy area expertise relates to specific clinical indications that you have worked in

- Examples include respiratory, immuno-oncology, rare diseases, cardiovascular disease, metabolic disease, etc.

- Target expertise relates to those mechanisms that you have worked on

- Examples include ion channels, G-protein coupled receptors (GPRs), kinases, receptor tyrosine kinases (RTKs), etc.

- Modality experience relates to the type of assets that you have worked on

- Examples include small molecules, antibodies, peptides/proteins, gene therapy, bioelectronics, vaccines, cell therapy, etc.

- Pipeline experience relates to the area of the drug discovery and development pipeline that you worked in

- Examples include target identification, target validation, candidate selection, safety assessment, translational science, clinical pharmacology, clinical trials, full development, etc.

- Process experience relates to generally applicable experience that is independent of the above

- $\quad$ Examples include regulatory, project management, project leadership, safety assessment, operations, intellectual property, legal, financial, etc.

It is important to have a clear idea of which of those areas you would be comfortable consulting on and to optimize your client base using as many of these areas in combination as possible (Figure 1). It's also worth considering your unique selling point, which makes you stand out from the crowd, there are lots of other highly competent individuals competing for business.

\section{Clients}

There are different types of clients too, ranging from academia, through biotech to big pharmaceutical companies, each with different requirements.

- Consulting for academic institutions often involves translating their novel experimental findings into a form that adds value and impacts human health. The academic inventions are generally very early in the drug discovery and development process (e.g., discovery of a new target to treat disease, a new technology, etc). A challenge in this area is to maintain the balance between the academic need to publish and the business need to protect intellectual property. In addition, the experimental work required to generate the next high impact publication is not the same as that required to move an invention toward a product. For this process to be successful, there is a need to be cognizant of the potentially conflicting priorities of publish or patent. I believe that an underlying cause of this potential conflict is the way in which academics are rewarded, namely individual work rather than collaboration and high impact publications, sometimes to the detriment of intellectual property.

- Consulting for biotech companies is, in my opinion, the most scientifically interesting and demanding area. These companies have progressed beyond the initial scientific discovery and have attracted a level of funding. They are therefore driven by various time and money constraints that are different from academics and large pharma companies. It is important to understand the strategy and business plan of your client in order to effectively support them to manage risk. Their needs are varied, ranging from general consulting on specific issues, through writing position pieces and risk assessments up to general project leadership and everything in between. It is important to set expectations for the client and to ensure that they are aware of your way of working (face to face meetings, number of hours, availability, travel, etc).

- Consulting for large pharmaceutical companies is different from academia and biotech. Pharma companies generally have teams of expert employees working in similar areas and may require your specific expertise to supplement existing capabilities. This can provide new challenges in integrating into an existing team and finding a way to effectively add value to the project. 


\section{Paperwork}

Paperwork is important, even if it's virtual paper. By this I mean all the documents required to set up and manage a new client. Initially, a confidentiality agreement needs to be agreed and signed, for you and the client to scope out the required work. If these initial discussions are productive then you can move to drawing up a suitable contract. You can write your own template contract (there are also websites offering free contract templates), but I find that most clients have their own. Read it carefully, even though it's sometimes difficult to understand. Ask for clarification and alterations if there are any clauses that make you uncomfortable. Generally, it takes a few iterations to finalize a contract that's acceptable to everyone. If you are unsure, seek legal advice - there are legal companies that specialize in biotech and will ensure that you are compliant with legislation [5,6].

The actual work to be done is usually added as an appendix to the contract that defines the scope and the timelines. In my experience this can be very brief (a few paragraphs) but for others a more detailed description may be required. Your fees should also be negotiated and added to the contract. An hourly or daily rate is usual, but a fee for a defined piece of work is also possible, it depends on your preference. If you get it wrong the first time then you will not make that mistake again. It's difficult to find information that helps you determine a fee structure, but this website may be useful as a starting point $[7]$.

Do not forget to meticulously record your billable hours and track your progress toward milestones. This information is crucial for accurate book keeping and invoicing. Some consultants do all of the financials themselves, others contract it out and others have a combination approach. Overall, remember that if you do not send out accurate invoices every month then you will not get paid. In the UK, you need not add value added tax (VAT) to your fees, however if your annual income exceeds $£ 85,000$ then you are obliged to register for VAT [8]. Wherever you are, tax needs to be considered.

\section{Conflict of interest}

One needs to think about potential conflicts of interest and how to manage them. For each new contract, it is important to consider how it fits into your portfolio of contracts and consider potential overlaps. I find that having a frank discussion of potential conflicts of interest with each client works best. Obviously, working for two clients that are in competition would be a conflict of interest, but it's not always so clear-cut and may need some thought and discussion.

\section{Continuing professional development}

Continuing professional development is a subject very close to my heart. When I was working for a large pharmaceutical company all my training needs were met by the company (training courses, conferences, mentoring, coaching, etc.). Now that I am independent, I must provide my own development and training opportunities. I also keep a record of my training and an up-to-date curriculum vitae as you never know when a client may ask for it. Some suggestions for maintaining and continuing your professional development:

- Join a professional body and keep up-to-date with their posts and meetings.

- Read the scientific literature (you will have to do this as part of your consulting work anyway) and document how you used the information.

- Speak to key opinion leaders and document your discussions. This generally happens as part of your consulting work on behalf of the client, but it is valuable learning for you too.

- Keep up-to-date on the regulatory guidelines (e.g., European Medicines Agency [EMA] and the US FDA).

- If you are involved in any aspect of clinical trials, then you must keep up-to-date on the elements of Good Clinical Practice (GCP) [9].

- Attend conferences (there are lots of free/inexpensive local conferences) and document what you learned and how it impacted your work.

- Share best practice with other independent consultants.

- Use social media (blogs, twitter) and so on to keep up-to-date.

There are also a whole range of 'soft' skills required to be a successful independent consultant. These include communication, flexibility, resilience, rigor, discipline, integrity, transparency, reliability, consistency, honesty, and so on. Your reputation is precious, and these soft skills are your best tools to preserve that reputation. 
What have you learned over the past 3 years?

Over the past 3 years, I have discovered that I really enjoy working as a consultant; the variety, autonomy and flexibility really suit my way of working. While I miss working as part of a team, I am building a new team of peers who are also independent consultants. I also enjoy the running of a small business, although the transition from full-time employee to business owner was not easy.

Effort tracking has become essential rather than a burden. I make sure that I track 'billable hours' when I am adding value to the clients' projects. I do not get paid anymore when I'm on holiday or having coffee with colleagues.

Managing my portfolio of clients can be tricky. You need to maintain a balance between new clients coming in and completed contracts coming to an end. Managing client expectations can also be difficult as urgent deadlines for different clients can converge, despite your best efforts.

Finally, sometimes your professional opinion is not palatable to the client. However, I believe that you are being paid to have an opinion, so you better provide it, even if it's not what they want to hear.

\section{What do you think are your challenges for the future?}

The biotech landscape is changing all the time in the UK and the role of the independent consultant will, undoubtedly, evolve in parallel. There is much more diversity in the biotech industry and so it's essential for consultants to keep abreast of developments. There are signs that independent consultants are forming loose connections with other consultants to support each other. I think this is healthy and provides access to new areas of expertise, sharing of best practice and continuing development. Perhaps, one day, independent consultants will have their own professional body that accredits its members.

\section{Financial \& competing interests disclosure}

The author has no relevant affiliations or financial involvement with any organization or entity with a financial interest in or financial conflict with the subject matter or materials discussed in the manuscript. This includes employment, consultancies, honoraria, stock ownership or options, expert testimony, grants or patents received or pending, or royalties.

No writing assistance was utilized in the production of this manuscript.

Interview disclosure

The opinions expressed in this interview are those of PT Lukey and do not necessarily reflect the views of Future Science Ltd.

\section{Open access}

This work is licensed under the Attribution-NonCommercial-NoDerivatives 4.0 Unported License. To view a copy of this license, visit http://creativecommons.org/licenses/by-nc-nd/4.0/

\section{References}

1. Campion N. Limited company advantages and disadvantages. Rapid Formations, London, UK (2015). www.rapidformations.co.uk/blog/limited-company-advantages/

2. GOV.UK. Companies house. www.gov.uk/government/organisations/companies-house

3. GOV.UK. Guide to the general data protection regulation. (2018). www.gov.uk/government/publications/guide-to-the-general-data-protection-regulation

4. United Kingdom Science Park Association. www.ukspa.org.uk/members/our-members

5. GOV.UK. Off-payroll working through an intermediary (IR35). (2017). www.gov.uk/guidance/ir35-find-out-if-it-applies

6. Wikipedia. IR35. (2018). en.wikipedia.org/wiki/IR35

7. Crane M. How to set your consulting fees. Forbes, Jersey City, NJ, USA (2006). www.forbes.com/2006/11/06/bostonconsulting-marsh-mckinsey-ent-fin-cx_mc_1106pricing.html\#438b0baf6781

8. GOV.UK. VAT registration thresholds. (2017). www.gov.uk/vat-registration-thresholds

9. International Council for Harmonization of Technical Requirements for Pharmaceuticals for Human Use. Training (2018). www.ich.org/trainings/training.html 